Original Article

\title{
Detection of respiratory viruses and expression of inflammatory cytokines in patients with acute exacerbation chronic obstructive pulmonary disease in Mongolia China
}

\author{
Detecção de vírus respiratórios e expressão de citocinas inflamatórias em pacientes \\ com doença pulmonar obstrutiva crônica de exacerbação aguda na Mongólia, China
}

\author{
Y. Fenga (D), E. Liü ${ }^{\mathrm{b} *}$ (D) \\ aPeople's Hospital of Xing'an League, Department of Clinical Laboratory, Ulanhot, Inner Mongolia, China \\ 'Hulunbeier People's Hospital, Hulunbuir Clinical Medical College, Department of Clinical Laboratory, Inner Mongolia University for \\ Nationalities, Hulunbeier, Inner Mongolia 021008, China
}

\begin{abstract}
Chronic obstructive pulmonary disease (COPD) was estimated to be the third cause of global mortality by 2020 . Acute exacerbation COPD (AECOPD) is a sudden worsening of COPD symptoms and could be due to virus/bacterial infections and air pollution. Increased expression of inflammatory markers in patients with AECOPD is associated with viral infection. This study aimed to detect different viruses and analyze the expression of various inflammatory markers associated with AECOPD patients. Three hundred and forty-seven patients diagnosed with COPD according to GOLD criteria were included in this study. Swab samples and blood were collected for the detection of viruses by RT-PCR and expression of inflammatory markers, respectively. Of the swab samples, 113 (32.6\%) of samples were positive for virus detection. Of these, $\operatorname{HRV}(39.8 \%)$ was the predominant virus detected followed by FluB (27.4\%) and FluA (22.1\%). The presence of HRV was significantly higher $(\mathrm{p}=0.044)$ among the other detected viruses. When compared to healthy controls the expression levels of TNF- $\alpha$, IL- 6 and IL- 8 were significantly higher $(\mathrm{p}<0.05)$ in virus-positive patients. The IL- 6 and IL- 8 were the next predominantly expressed in markers among the samples. The higher expression rate of IL- 8 was significantly $(\mathrm{p}<0.05)$ associated with patients having COPD GOLD III severity level and smoking history. Although HRV was the predominant virus detected the combined prevalence of Influenza A and B surpassing the rate of HRV. The high-level expression of well known inflammatory markers of AECOPD, TNF- $\alpha$, IL- 6 and IL- 8 indicates a chronic severe illness. These markers play an important role and could be used as a marker for determining the severity of AECOPD.
\end{abstract}

Keywords: respiratory virus, AECOPD, inflammatory cytokines.

\begin{abstract}
Resumo
Estima-se que a doença pulmonar obstrutiva crônica (DPOC) seja a terceira causa de mortalidade global em 2020. A exacerbação aguda DPOC (AECOPD) é um agravamento súbito dos sintomas da DPOC e pode ser devido a infecções por vírus/bactérias e poluição do ar. O aumento da expressão de marcadores inflamatórios em pacientes com AECOPD está associado à infecção viral. Este estudo teve como objetivo detectar diferentes vírus e analisar a expressão de vários marcadores inflamatórios associados a pacientes com AECOPD. Trezentos e quarenta e sete pacientes com diagnóstico de DPOC de acordo com os critérios GOLD foram incluídos neste estudo. Amostras de swab e sangue foram coletadas para detecção de vírus por RT-PCR e expressão de marcadores inflamatórios, respectivamente. Das amostras de esfregaço, 113 (32,6\%) amostras foram positivas para detecção de vírus. Nestas, o $\operatorname{HRV}(39,8 \%$ ) foi o vírus predominante detectado, seguido do $\operatorname{FluB}(27,4 \%)$ e do FluA (22,1\%). A presença de VFC foi significativamente maior ( $\mathrm{p}=0,044)$ entre os demais vírus detectados. Quando comparados a controles saudáveis, os níveis de expressão de TNF- $\alpha$, IL-6 e IL-8 foram significativamente maiores $(p<0,05)$ em pacientes com vírus positivo. A IL-6 e a IL-8 foram as próximas predominantemente expressas em marcadores entre as amostras. A maior taxa de expressão de IL-8 foi significativamente $(p<0,05)$ associada a pacientes com grau de gravidade GOLD III da DPOC e história de tabagismo. Embora o HRV tenha sido o vírus predominante, a prevalência combinada de Influenza A e B ultrapassou a taxa de HRV. $\mathrm{O}$ alto nível de expressão de marcadores inflamatórios bem conhecidos de AECOPD, TNF- $\alpha$, IL-6 e IL- 8 indica uma doença crônica grave. Esses marcadores desempenham um papel importante e podem ser usados como um marcador para determinar a gravidade da AECOPD.
\end{abstract}

Palavras-chave: vírus respiratório, AECOPD, citocinas inflamatórias.

*e-mail: 1461073289@qq.com

Received: September 26, 2019 - Accepted: July 10, 2020

This is an Open Access article distributed under the terms of the Creative Commons Attribution License, which permits unrestricted use, distribution, and reproduction in any medium, provided the original work is properly cited. 


\section{Introduction}

Chronic obstructive pulmonary disease (COPD) is a common inflammatory and respiratory disease which is preventable and treatable. It is characterized by persistent respiratory symptoms and irreversible airflow limitation due to airway/alveolar abnormalities caused by noxious particles or gases (WHO, 2019). COPD is the fourth leading cause of death and estimated to become the third leading cause of death in 2020, worldwide (GOLD, 2019). COPD is higher in patients with smoking history, in those with more than 40 years of age and in men (Halbert et al., 2006). The estimated pooled prevalence of COPD in adults aged more than 40 years of age was $9 \%-10 \%$. Mortality rates due to COPD varies with countries, the reported mortality rate in Japan was 4.4 per 100,000 population and 130 per 100,000 population in China. Due to the increase in the aging population in high-income countries and increase in the prevalence of smoking in developing countries, the prevalence of COPD will be on the rise and it was estimated that by 2030 over 4.5 million death may occur due to COPD and related conditions (Lopez et al., 2006).

In patients with COPD, acute exacerbation is considered as the main cause of mortality (Almagro et al., 2015). COPD exacerbation is defined as an acute worsening of respiratory symptoms that resulted in additional therapy. It was classified as mild: treated with shortacting bronchodilators (SABDs), moderate: treated with oral corticosteroid and/or antibiotics, severe: patients requiring hospitalization and visit emergency room (Wedzicha and Seemungal, 2007). Air pollution, bacterial and viral infections are the main etiological agents of acute exacerbation of COPD (AECOPD). Among these, bacterial and viral infections are highly associated with AECOPD with virus accounting for $40 \%$ of the overall incidence. Of these, human rhinovirus (HRV) was the predominant etiological agent accounting approximately 58\%. Other viral pathogens include influenza virus (Flu), human adenovirus (HADV), respiratory syncytial virus (RSV), parainfluenza virus (PIV) and human coronavirus (HCoV) (Hudy et al., 2014; Kwak et al., 2016). Unlike bacteria, virus is hard to isolate and identify. The advent of nucleic acid-based molecular tools paved the way for easy and accurate identification of respiratory viruses in AECOPD patients (Zheng et al., 2017). This led to increased recognition of virus detection in AECOPD patients (Yin et al., 2018).

Host inflammatory response plays a vital role in viral AECOP. During airway inflammation in AECOPD, several inflammatory markers were produced. The high-level production of airway pro-inflammatory cytokines such as Interleukin-6 (IL-6) and Interleukin-8 (IL-8) is associated with viral AECOPD (Kurai et al., 2013; Matsumoto and Inoue, 2014; Piper et al., 2013). The availability of specific inflammatory markers could help for the easy and quick identification of viral infection in AECOPD. However, data on the association of inflammatory markers with AECOPD of viral origin is sparse. Thus, an evaluation to find out the relationship between the inflammatory markers and viral AECOPD will help in better understanding of AECOPD pathogenesis. This study detected respiratory viruses and analyzed the expression of inflammatory cytokines in patients with AECOPD in China.

\section{Methods}

\subsection{Patient and clinical data}

Three hundred and forty-seven patients with AECOPD admitted in People's Hospital of Xing'an League, Ulanhot, Inner Mongolia, China and Hulunbeier People's Hospital, Hulunbuir Clinical Medical College, Inner Mongolia University for Nationalities, Hulunbeier, Inner Mongolia 021008, China between March 2017 and May 2019 were included. All patients were diagnosed with COPD as per GOLD criteria (post-bronchodilator forced expiratory volume in 1 second (FEV1) to forced vital capacity (FVC) ratio $<70 \%$ and post-bronchodilator FEV1 <80\%) (Vestbo et al., 2013). Patients with two major symptoms such as increased sputum production, increased dyspnea, enhance cough or one minor and one major symptom such as congestion/nasal discharge, sore throat, wheezing, cough for at least two consecutive days was identified as AECOPD patients (Zheng et al., 2017). In addition, 20 healthy controls were also included in the analysis. Patients with following conditions were excluded: who were not willing to participate, who did not undergo complete pulmonary function test, patients with prior anti-viral treatment and patients with other diseases including lung cancer, bronchiectasis, asthma, mental disorder, myocardial infarction, unstable angina, tuberculosis and other chronic respiratory diseases. Demographic and clinical data including age, gender, smoking history, stage of COPD according to GOLD criteria, comorbidities and duration of antibiotic usage were collected. Informed consent was obtained from the patients or their legal heirs. The institutional ethics committee approved the study (016-2017).

\subsection{Sample Collection}

Throat swabs were collected from patients with AECOPD within 24 hours of hospital admission, aseptically. The collected swabs were then transported to the laboratory in sterile screw-capped tubes containing minimum essential media (Sigma, USA) supplemented with penicillin (2000 U/mL), gentamicin (1.5 mg/mL), amphotericin B $(2 \mu \mathrm{g} / \mathrm{mL})$ and fetal bovine serum (1.5\%). The samples were immediately processed or temporarily stored at $4^{\circ} \mathrm{C}$ and processed within 48 hours. Blood samples from each patient for the inflammatory marker analysis were collected, serum was separated and stored at $-40^{\circ} \mathrm{C}$ until used.

\subsection{RNA Extraction}

RNA from the throat swabs were extracted using PureLink $^{\mathrm{TM}}$ RNA Mini Kit (Thermo Fischer, USA) as per manufacturer's instructions. RNA quantification and purity were determined using NanoDrop ${ }^{\mathrm{TM}}$ spectrophotometer (Thermo Fischer, USA). Quantified RNA was then stored at $-80^{\circ} \mathrm{C}$ until used. 


\subsection{Detection of Virus by $R T-P C R$}

One-step Real-Time quantitative PCR was performed to detect viruses with the primers described by Yin et al. (Yin et al., 2018). The QuantStudio ${ }^{\mathrm{TM}} 7$ Flex Real-Time PCR System (Applied Biosystems) was used in this study. Respiratory viruses including HRV, RSV Type A (RSVA), RSV Type B (RSVB), HADV, Flu Type A (FluA), Flu Type B (FluB), PIV, HCoV, Human Metapneumovirus (HMPV), and Human Bocavirus (HBoV) were detected using virusspecific primers (Table 1). A $25 \mu \mathrm{L}$ PCR master mix consists of $12.5 \mu \mathrm{L}$ of TaqMan ${ }^{\circledR}$ Fast Advanced Master Mix (Thermo Fischer, USA), $0.5 \mu \mathrm{L}$ of each primer, $0.5 \mu \mathrm{L}$ of probe, $2.5 \mu \mathrm{L}$ of RNA and $9 \mu \mathrm{L}$ of molecular grad PCR water. PCR cycling condition include: $42^{\circ} \mathrm{C}$ for 10 minutes (reverse transcription), $95^{\circ} \mathrm{C}$ for 1 minute (pre-degeneration), $95^{\circ} \mathrm{C}$ for 5 seconds (degeneration), 40 cycles at $60^{\circ} \mathrm{C}$ for 30 seconds (annealing extension and fluorescence collection). Fluorescence probes used included FAM, CY3 and HEX. Amplification data were analyzed using the inbuilt software of the system. The reaction was performed

Table 1. Primer and probe sequences.

\begin{tabular}{|c|c|c|c|}
\hline Primers and probes & Base sequence $\left(5^{\prime}-3^{\prime}\right)$ & Base group region & Fragment length (bp) \\
\hline \multirow[t]{3}{*}{ HRV } & F: AGCCTGCGTGGCTGCC & 5'UTR & 200 \\
\hline & R: GAAACACGGACACCCAAAGTAGT & & \\
\hline & Probe: CTCCGGCCCCTGAATGYGGCTAA & & \\
\hline \multirow[t]{3}{*}{ Flu A } & F: GACCRATCCTGTCACCTCTGAC & M & 106 \\
\hline & R: AGGGCATTYTGGACAAAKCGTCTA & & \\
\hline & Probe: TGCAGTCCTCGCTCACTGGGCACG & & \\
\hline \multirow[t]{3}{*}{ Flu B } & F:CCCACCRAGCAACAAACG & NP & 76 \\
\hline & R: CCTTCCGACATCAGCTTCACT & & \\
\hline & Probe: CCCGGAACCCATCCCCGGA & & \\
\hline \multirow[t]{3}{*}{ RSV A } & F: GCTCTTAGCAAAGTCAAGTTGAATGA & $\mathrm{N}$ & 82 \\
\hline & R: TGCTCCGTTGGATGGTGTATT & & \\
\hline & Probe: ACACTCAACAAAGATCAACTTCTGTCATCCAGC & & \\
\hline \multirow[t]{3}{*}{ RSV B } & F: GATGGCTCTTAGCAAAGTCAAGTTAA & $\mathrm{N}$ & 104 \\
\hline & R: TGTCAATATTATCTCCTGTACTACGTTGAA & & \\
\hline & Probe: TGATACATTAAATAAGGATCAGCTGCTGTCATCCA & & \\
\hline \multirow[t]{3}{*}{ HADV } & F: GCCACGGTGGGGTTTCTAAACTT & Hexon & 133 \\
\hline & R: GCCCCAGTGGTCTTACATGCACATC & & \\
\hline & Probe: TGCACCAGACCCGGGCTCAGGTACTCCGA & & \\
\hline \multirow[t]{3}{*}{ PIV } & F: ACCTACAAGGCAACAACATC & HN & 129 \\
\hline & R: CTTCCTGCTGGTGTGTTAAT & & \\
\hline & Probe: GCTGCCCAAACGATGGCTGAAAAAGGGAGGCAGC & & \\
\hline \multirow[t]{3}{*}{ HCoV } & F: GGTTGGGACTATCCTAAGTGTGA & RDRP & 440 \\
\hline & R: CCATCATCAGATAGAATCATCATA & & \\
\hline & Probe: ATCGTAATCCGGCTGAC & & \\
\hline \multirow[t]{3}{*}{ HBoV } & F: CAGCCACCTATCGTCTTGCA & NP-1 & 123 \\
\hline & R: GCTCTGTGTTGACTGAATACAGT & & \\
\hline & Probe: CTGCTTCGAAGACCTCAGACCAAGTGATG & & \\
\hline \multirow[t]{3}{*}{ HMPV } & F: AACCGTGTACTAAGTGATGCACTC & NP & 213 \\
\hline & R: CATTGTTTGACCGGCWCCATAA & & \\
\hline & Probe: GCTTTGCTTCCTGTTGAAGATGAGCCT & & \\
\hline
\end{tabular}

Abbreviation: Flu A, influenza virus type A; F, forward primer; R, reverse primer; P, probe; M, matrix protein; Flu B, influenza virus type B; NP, nucleocapsid protein; HADV, human adenovirus; Hexon, hexapeptide protein; RSVA, respiratory syncytial virus type A; N, nucleoprotein; RSVB, respiratory syncytial virus type B; HRV, rhinovirus; 5`UTR, 5'-untranslated region; PIV, parainfluenza virus; HN, hemagglutinin-neuraminidase protein; HCoV, human coronavirus; RDRP, RNA-dependent RNA polymerase; HBoV, human bocavirus; NP-1, nonstructural protein; HMPV, human metapneumovirus. 
in triplicates if good sample curve was obtained in two of the three triplicates within the <35-cycle cut-off, the sample was considered as positive.

\subsection{Inflammatory Marker Analysis}

Serum samples stored at $-40^{\circ} \mathrm{C}$ were used for the detection of inflammatory markers. Forty different human cytokines were analyzed using Quantibody ${ }^{\circledR}$ Human Inflammation Array 3 kit (Ray Biotech, USA) as per manufacturer's instructions (Table 2).

\subsection{Statistical Analysis}

Chi-Square, Man-Whitney and Pearson correlation coefficient tests were performed using MINITAB statistical software (MINITAB, Ver. 13, USA). A P value of $<0.05$ was considered statistically significant.

\section{Results}

\subsection{Patients}

Of the 347 patients, 193 (55.6\%) were male and 154 (44.4\%) were female (mean age $48.5 \pm 7.5$ years). The majority of the included patients $(97,28.0 \%)$ were aged between 51 and 60 years. The COPD severity level in 18 (5.2\%) patients were classified as GOLD I, 112 (32.3\%) patients as GOLD II, 185 (53.3\%) patients as GOLD III and $32(9.2 \%)$ patients as GOLD IV. A significantly higher number of patients were classified to have GOLD III level of severity ( $\chi^{2}$ Test, $\mathrm{p}=0.021$ ). Fifty-two (15\%) patients had prior COPD and $88(25.4 \%)$ had exacerbation for more than 4 days. One hundred and forty-two (40.9\%) patients were identified as current smokers and $93(26.8 \%)$ patients had a history of smoking. One hundred and thirteen $(32.6 \%)$ patients had cough and 47 (13.5\%) had sore throat. The baseline characteristics of overall patients were described in Table 3.

\subsection{Virus Detection}

Of the 347 samples tested, 113 (32.6\%) of samples were positive for virus detection. Of the 113 viruspositive samples, HRV $(45,39.8 \%)$ was the predominant virus detected followed by FluB (31, 27.4\%) and FluA (25, $22.1 \%)$. The presence of HRV was significantly higher $\left(\chi^{2}\right.$ Test, $\mathrm{p}=0.044$ ) among the samples. HBoV was the least common virus detected among our samples (Figure 1).
None of the samples amplified HMPV. Seventeen patients had multi-virus infections; HRV along with Flu B (5, 4.4\%) was the most predominant combination, HRV along with Flu B $(4,3.5 \%)$ was the second most common combination found among the patients. One patient had HRV, Flu A and Flu B were detected (Table 4).

When analyzed the baseline characteristics among virus-positive and virus-negative patients, virus detection was significantly higher $(41,36.3 \%$; $\mathrm{p}=0.012)$ in patients within the age group of 61-70 years. Compared to virus-negative patients, exacerbation for more than 4 days (42, 37.2\%; $\mathrm{p}=0.035)$, running nose $(28,24.8 \%$; $\mathrm{p}=0.023)$ and cough $(53,46.9 \%$; $=0.016)$ were significantly higher in virus-positive patients. Whereas virus detection was significantly lower (24, 21.2\%; $\mathrm{p}=0.025)$ among non-smokers (Table 3).

\subsection{Expression of Inflammatory Markers}

Of the 40 different inflammatory markers tested, the majority of the samples revealed that the expression rate of TNF- $\alpha$ was higher compared to other tested markers. The IL- 6 and IL-8 were the next predominantly expressed markers among the samples. The expression array showed that the levels of TNF- $\alpha$, IL- 6 and IL- 8 were significantly

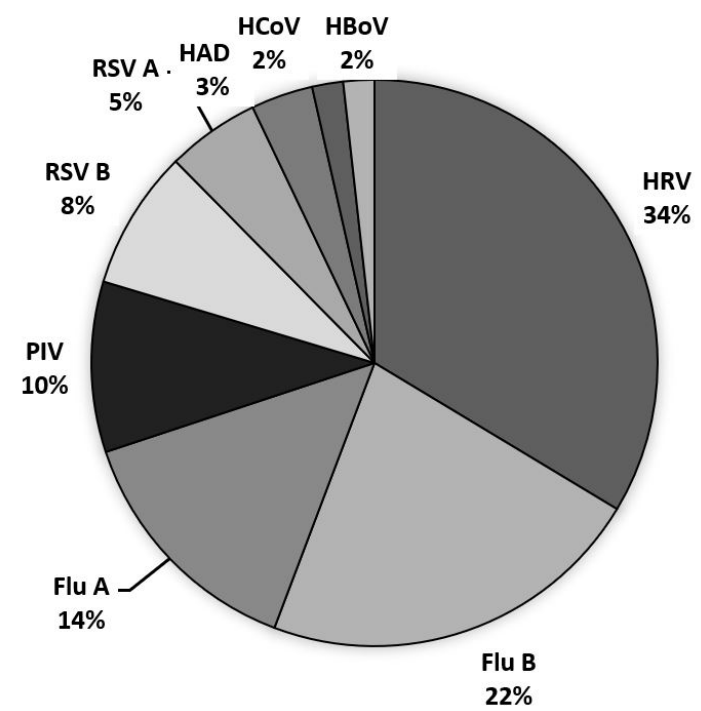

Figure 1. Distribution of Viruses.

Table 2. Inflammatory markers detected.

\begin{tabular}{ccccc}
\hline BLC (CXCL13) & Eotaxin-1 (CCL11) & Eotaxin-2 (MPIF-2/CCL24) & GCSF & GM-CSF \\
\hline I-309 (TCA-3/CCL1) & ICAM-1 (CD54) & IFN-gamma & IL-1 alpha (IL-1 F1) & IL-1 beta (IL-1 F2) \\
IL-1 ra (IL-1 F3) & IL-2 & IL-4 & IL-5 & IL-6 \\
IL-6 R & IL-7 & IL-8 (CXCL8) & IL-10 & IL-11 \\
IL-12 p40 & IL-12 p70 & IL-13 & IL-15 & IL-16 \\
IL-17A & MCP-1 (CCL2) & M-CSF & MIG (CXCL9) & MIP-1 alpha (CCL3) \\
MIP-1 beta (CCL4) & MIP-1 delta (CCL15) & PDGF-BB & RANTES (CCL5) & TIMP-1 \\
TIMP-2 & TNF alpha & TNF beta (TNFSF1B) & TNF RI (TNFRSF1A) & TNF RII (TNFRSF1B) \\
\hline
\end{tabular}


Table 3. Baseline characteristics of overall, virus positive and negative patients.

\begin{tabular}{|c|c|c|c|}
\hline & $\begin{array}{l}\text { Total No of patients } \\
\qquad(n=347)\end{array}$ & $\begin{array}{l}\text { Virus Positive Patients } \\
\qquad(\mathrm{n}=113)\end{array}$ & $\begin{array}{l}\text { Virus Negative Patients } \\
\qquad(n=234)\end{array}$ \\
\hline Male & $193(55.6 \%)$ & $64(56.6 \%)$ & $129(55.1 \%)$ \\
\hline Female & $154(44.4 \%)$ & $49(43.4 \%)$ & $105(44.9 \%)$ \\
\hline Mean age (SD) & $48.5 \pm 7.5$ years & $54.3 \pm 3.3$ years & $35.5 \pm 5.9$ years \\
\hline Less 40 years & $61(17.6 \%)$ & $8(7.1 \%)$ & $53(22.6 \%)$ \\
\hline $41-50$ years & $59(17.0 \%)$ & $21(18.6 \%)$ & $38(16.2 \%)$ \\
\hline $51-60$ years & $97(28.0 \%)$ & $33(29.2 \%)$ & $64(27.4 \%)$ \\
\hline $61-70$ years & $77(22.2 \%)$ & $41(36.3 \%)^{*}$ & $36(15.4 \%)$ \\
\hline 71 years and above & $53(15.3 \%)$ & $10(8.8 \%)$ & $43(18.4 \%)$ \\
\hline Current smokers & $142(40.9 \%)$ & $54(47.8 \%)$ & $88(37.6 \%)$ \\
\hline Patients with previos smoking history & $93(26.8 \%)$ & $35(31.0 \%)$ & $58(24.8 \%)$ \\
\hline Non-smokers & $112(32.3 \%)$ & $24(21.2 \%)$ & $88(37.6 \%)^{*}$ \\
\hline Prior COPD & $52(15.0 \%)$ & $21(18.6 \%)$ & $31(13.2 \%)$ \\
\hline Exacerbation for $>=5$ days & $88(25.4 \%)$ & $42(37.2 \%)^{*}$ & $46(19.7 \%)$ \\
\hline Fever & $54(15.6 \%)$ & $21(18.6 \%)$ & $33(14.1 \%)$ \\
\hline Running nose & $38(11.0 \%)$ & $28(24.8 \%)^{*}$ & $10(4.3 \%)$ \\
\hline Sore throat & 47 (13.5\%) & $16(14.2 \%)$ & $31(13.2 \%)$ \\
\hline Cough & $113(32.6 \%)$ & $53(46.9 \%)^{*}$ & $60(25.6 \%)$ \\
\hline Weezing & $29(8.4 \%)$ & $13(11.5 \%)$ & $16(6.8 \%)$ \\
\hline Chest pain & $21(6.1 \%)$ & $10(8.8 \%)$ & $11(4.7 \%)$ \\
\hline Discolored sputum & $49(14.1 \%)$ & $25(22.1 \%)$ & $24(10.3 \%)$ \\
\hline Prior antibiotic treatment & $131(37.8 \%)$ & $39(34.5 \%)$ & $92(39.3 \%)$ \\
\hline
\end{tabular}

*Man-Whitney test: Values were signignificant $(\mathrm{p}<0.05)$ when compared between virus positive and virus negative patients
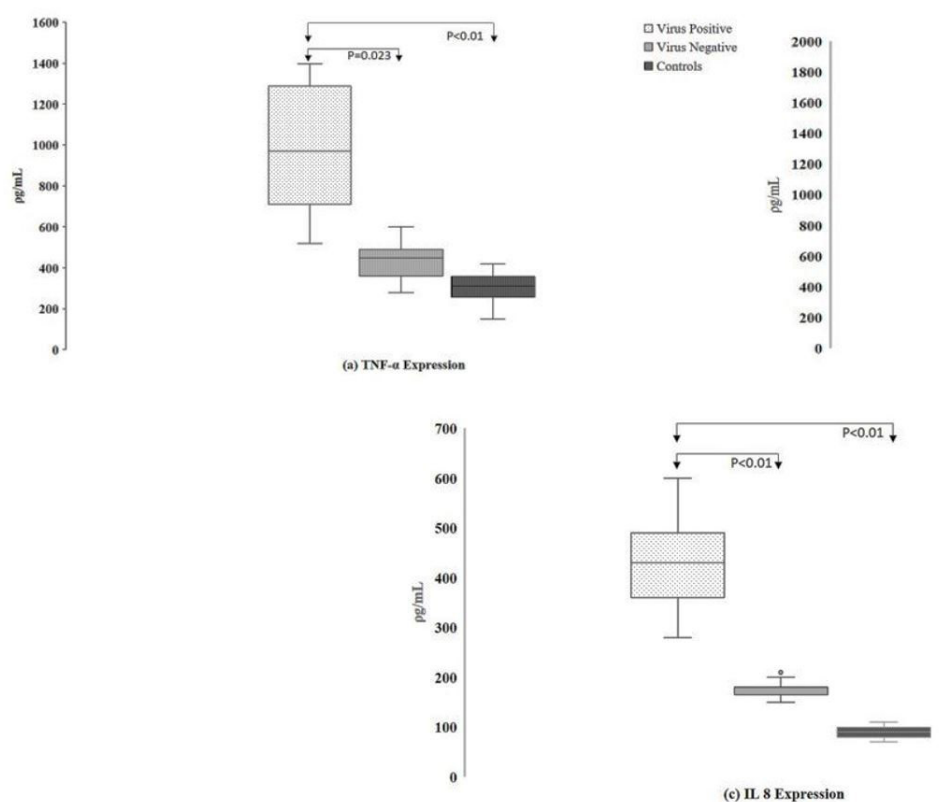

Figure 2. Over expression of (a) TNF- $\alpha$, (b) IL 6, (c) IL 8.
口 Virus Positive Virus Negative - Controls

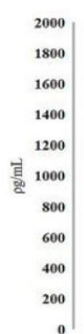

¿Virus Positive

$\square$ Virus Negative - Controls 
Table 4. Distribution of different virus combination among AECOPD patients.

\begin{tabular}{cc}
\hline Virus Combination & No of Patients \\
\hline HRV + Flu B & $5(4.4 \%)$ \\
HRV + Flu A & $4(3.5 \%)$ \\
Flu A + Flu B & $3(2.7 \%)$ \\
RSV A + RSV B & $3(2.7 \%)$ \\
Flu A + RSV B & $1(0.9 \%)$ \\
HRV + Flu A +Flu B & $1(0.9 \%)$ \\
\hline
\end{tabular}

higher in virus-positive patients $(p=0.023, p<0.01, p<0.01$ respectively) compared to healthy controls $(\mathrm{p}<0.01, \mathrm{p}<0.01$, $\mathrm{p}<0.01$ respectively), respectively (Figure 2 ). There was no significant difference $(p>0.05)$ in the level of TNF- $\alpha$, IL-6 and IL- 8 expression between virus-negative patients and healthy controls. A correlation coefficient analysis revealed that the higher expression rate of IL-8 was significantly associated with patients having COPD GOLD III severity level $(\mathrm{r}=0.9 ; \mathrm{p}=0.036)$ and smoking history $(\mathrm{r}=0.89 ; \mathrm{p}=0.042)$. The expression level of other tested inflammatory markers though was higher in virus-positive patients compared to virus-negative patients, they did not differ significantly.

\section{Discussion}

COPD, a common inflammatory respiratory disease is highly associated with the inflammatory marker expression, so as viral infections. Viral infection in COPD especially AECOPD patients were associated with increased expression of inflammatory markers (Triantafilou et al., 2013). However, yet there was no clear and specific association established between them. In our study, 32.6\% of AECOPD patients were tested positive for viral infection. Our result was comparable (36.7\%) to that reported in a meta-analysis from Iran (Jafarinejad et al., 2017) and another study from Hongkong (35.1\%) (Ko et al., 2019). However, higher than that reported from China (27.3\%) (Yin et al., 2018) and India (19.7\%) (Koul et al., 2017). In this study, HRV was the most common virus detected and significantly higher (39.8\%, $\mathrm{p}=0.044)$ among other viruses. Our finding was corroborated with the findings from a meta-analysis (pooled prevalence $(95 \% \mathrm{CI}), 0.320(0.300$, $0.340)$ ) which determined the worldwide prevalence of viral infection among AECOPD patients (Jafarinejad et al., 2017). Similar to our findings, studies from United Kingdom (19.6\%) (Wilkinson et al., 2006), France (20\%) (Perotin et al., 2013), Australia (78.8\%) (Hutchinson et al., 2007), Spain (58.3\%) (Gallego et al., 2016) and China (33.3\%) (Du et al., 2017) reported HRV as the most common virus detected among patients with AECOPD. In contrast to this study, a study from China reported Flu A (10\%) as the predominant virus detected among the patients. The study reported that HRV as the third most common virus (4\%) detected, however, with very lower rates than that reported in this study (Zheng et al., 2017). Another study from China, which included 264 patients with AECOPD also reported Flu A as the most common (9.5\%) virus detected and HRV as the second most common (8\%) virus detected among the patients (Yin et al., 2018). Although these studies reported Flu $A$ as the most common virus detected among AECOPD patients, the rates were very low compared to this study (22.1\%). A meta-analysis that included 28 studies from different countries, reported that six studies from Spain, China, Iran, Japan, Australia and India reported Flu A as the most common virus detected among patients with AECOPD (Jafarinejad et al., 2017). HRV along with Flu B (4.4\%) was the most predominant combination reported in this study, while a study from China reported HRV along with Enterovirus as the most common combination among patients with AECOPD (Zheng et al., 2017). Similar to that reported by Yin et al., HRV, Flu A and Flu B were the major viruses detected and $\mathrm{HBoV}$ was detected at very low frequency in this study (Yin et al., 2018). None of our patient samples amplified HMPV, in contrast, Perotin et al. (Perotin et al., 2013) and Martinello et al. (Martinello et al., 2006) reported HMPV as the second most common virus detected among their samples. The variation and the predominance in the prevalence of viral infections might be due to several factors including geography, vaccination, economic status, season and so on (Clark et al., 2015). This study result indicate that there could be shift in the individual prevalence of viruses present in AECOPD patients in China, as most of the studies reported Flu A as the predominant virus isolated; HRV was the most prevalent virus isolated in this study. However, when combined the presence of Influenza A and B among AECOPD patients, the presence of influenza virus surpasses the rate of HRV. The extremely low (19\%) Influenza vaccination coverage in China could be a possible reason for this trend (Feng et al., 2010). This indicates that attention needs to be paid for the effective control of the Influenza virus among the rapidly aging population of China. Also, the differences in the detection rates of virus reiterate the need for periodic and continuous region-specific studies involving a larger population for effective control of the disseminating viruses.

Similar to that reported by Yin et al., dual viral infection was very low in this study. However, HRV + Flu B was the most common combination reported in this study while Yin et al. reported Flu A + Flu B and HRV + RSVA as the common combination (Yin et al., 2018). In this study, exacerbation for more than 4 days (37.2\%; $\mathrm{p}=0.035)$ and running nose ( $24.8 \%$; $\mathrm{p}=0.023$ ) were significantly higher in virus-positive patients. In contrast to this study, Zeng et al. reported that exacerbation for more than 4 days (40\%) and running nose $(45)$ were significantly higher $(\mathrm{p}<0.05)$ in virus-negative patients (Zheng et al., 2017). Although the specific age group was not mentioned, Yin et al., reported that virus detection was significantly higher in older patients. A similar result was obtained in this study where significantly higher $(\mathrm{p}=0.012)$ the number of patients within the age group of 61-70 years was found to be positive for virus detection. In contrast to that reported by Yin et al. virus positivity was associated with some of the clinical manifestations in this study (Yin et al., 2018).

The association of host cytokine response and viral infection in AECOPD patients was assessed through 40 different inflammatory markers. Among all the inflammatory markers tested the majority of samples 
revealed that the expression rate of $\mathrm{TNF}-\alpha$ was higher compared to other tested markers. The expression array showed that the levels of TNF- $\alpha$, IL- 6 and IL- 8 were significantly higher $(\mathrm{p}<0.05)$ in virus-positive patients compared to healthy controls. Our result corroborates with that reported by Zang et al., who also reported that TNF- $\alpha$, IL-6 and IL- 8 were the highly expressed inflammatory markers among AECOPD patients (Zhang and Bai, 2018). Similar to this study, Zeng et al. reported higher expression levels of TNF- $\alpha$ and IL- 6 in virus-positive patients. In addition to TNF- $\alpha$ and IL-6, IL- 8 was the third inflammatory marker which was highly expressed in virus-positive patients, while Zeng et al. reported MCP-1 (in addition to TNF- $\alpha$ and IL-6) as the highly expressed inflammatory marker among virus-positive patients (Zheng et al., 2017). There was no significant difference ( $p>0.05$ ) in the level of TNF- $\alpha$, IL-6 and IL-8 expression between virus-negative patients and healthy controls. This indicates that the difference in the marker expression could be due to viral infections. It was reported that TNF- $\alpha$, a mononuclear-phagocyte-origin cytokine, recruit inflammatory cells to the infected site and overexpressed in AECOPD patients (Pant et al., 2009; Strieter et al., 2003). The IL-6, a pleiotropic acute-phase cytokine, expressed during infection as part of the host immune response reflects the severity of lower airway inflammation. The higher the expression of IL- 6 the higher it is associated with the exacerbation of COPD patients. When combined with clinical diagnosis increased expression level of IL-6 was associated with increased predictive accuracy of viral infections. The IL-8, chemokine that was associated with the migration of neutrophils to airways is considered a possible target to assess COPD mortality and exacerbation (Zhang and Bai, 2018). Studies have reported that IL-8 levels can predict symptomatic recovery, clinical severity, bacterial infection, mortality of AECOPD and hypercapnia respiratory failure (Jónsdóttir et al., 2017; Koutsokera et al., 2013). COPD is higher in patients with smoking history (Halbert et al., 2006). Our study result corroborates the above findings, a correlation coefficient analysis revealed that the higher expression rate of IL- 8 was significantly associated with patients having COPD GOLD III severity level $(\mathrm{r}=0.9 ; \mathrm{p}=0.036)$ and smoking history $(\mathrm{r}=0.89 ; \mathrm{p}=0.042)$. The TNF- $\alpha$ and IL- 6 are well known traditional inflammatory mediators of AECOPD, in the current study IL-8 was also found with elevated expression levels similar to TNF- $\alpha$ and IL-6. The high expression of TNF- $\alpha$, IL- 6 and IL- 8 indicates a more likely chronic severe illness.

\section{Conclusion}

HRV was the predominant virus detected among AECOPD patients, however, the combined presence of Influenza $A$ and $B$ among AECOPD patients surpasses the rate of HRV and needs special attention for the effective control of Influenza infection. The high-level expression of well known inflammatory markers of AECOPD, TNF- $\alpha$, IL- 6 and IL-8 indicates a chronic severe illness. These markers play an important role and could be used as a marker for determining the severity of AECOPD. Further studies evaluating the expression level of these inflammatory markers and clinical conditions are needed.

\section{References}

ALMAGRO, P., HERNANDEZ, C., MARTINEZ-CAMBLOR, P., TRESSERRAS, R. and ESCARRABILL, J., 2015. Seasonality, ambient temperatures and hospitalizations for acute exacerbation of COPD: a population-based study in a metropolitan area. International Journal of Chronic Obstructive Pulmonary Disease, vol. 10, pp. 899-908. http://dx.doi.org/10.2147/COPD.S75710. PMid:26056439.

CLARK, T.W., MEDINA, M.J., BATHAM, S., CURRAN, M.D., PARMAR, S. and NICHOLSON, K.G., 2015. C-reactive protein level and microbial aetiology in patients hospitalised with acute exacerbation of COPD. The European Respiratory Journal, vol. 45, no. 1, pp. 76-86. http://dx.doi.org/10.1183/09031936.00092214. PMid:25186260.

DU, X.B., MA, X., GAO, Y., WEN, L.F., LI, J., WANG, Z.Z. and LIU, S., 2017. Prevalence and risk factors of respiratory viral infection in acute exacerbation of chronic obstructive pulmonary disease. Zhonghua Jie He He Hu Xi Za Zhi, vol. 40, no. 4, pp. 263-266. http://dx.doi.org/10.3760/cma.j.issn.1001-0939.2017.04.004. PMid:28395404.

FENG, L., MOUNTS, A.W., FENG, Y., LUO, Y., YANG, P., FENG, Z., YANG, W. and YU, H., 2010. Seasonal influenza vaccine supply and target vaccinated population in China, 2004-2009. Vaccine, vol. 28, no. 41, pp. 6778-6782. http://dx.doi.org/10.1016/j. vaccine.2010.07.064. PMid:20688038.

GALLEGO, M., POMARES, X., CAPILLA, S., MARCOS, M.A., SUAREZ, D., MONSO, E. and MONTON, C., 2016. C-reactive protein in outpatients with acute exacerbation of COPD: its relationship with microbial etiology and severity. International Journal of Chronic Obstructive Pulmonary Disease, vol. 11, pp. 2633-2640. http://dx.doi.org/10.2147/COPD.S117129. PMid:27799762.

GLOBAL INITIATIVE FOR CHRONIC OBSTRUCTIVE LUNG DISEASE - GOLD. 2019. [viewed 21 Sept 2019]. Global strategy fir the diagnosis management, and prevention of chronic obstructive pulmonary disease (2019 Report) [online]. Available from: https://goldcopd.org/gold-reports/.

HALBERT, R.J., NATOLI, J.L., GANO, A., BADAMGARAV, E., BUIST, A.S. and MANNINO, D.M., 2006. Global burden of COPD: systematic review and meta-analysis. The European Respiratory Journal, vol. 28, no. 3, pp. 523-532. http://dx.doi.org/10.1183/0903193 6.06.00124605. PMid:16611654.

HUDY, M.H., TRAVES, S.L. and PROUD, D., 2014. Transcriptional and epigenetic modulation of human rhinovirus-induced CXCL10 production by cigarette smoke. American Journal of Respiratory Cell and Molecular Biology, vol. 50, no. 3, pp. 571-582. http:// dx.doi.org/10.1165/rcmb.2013-01290C. PMid:24127910.

HUTCHINSON, A.F., GHIMIRE, A.K., THOMPSON, M.A., BLACK, J.F., BRAND, C.A., LOWE, A.J., SMALLWOOD, D.M., VLAHOS, R., BOZINOVSKI, S., BROWN, G.V., ANDERSON, G.P. and IRVING, L.B., 2007. A community-based, time-matched, case-control study of respiratory viruses and exacerbations of COPD. Respiratory Medicine, vol. 101, no. 12, pp. 2472-2481. http:// dx.doi.org/10.1016/j.rmed.2007.07.015. PMid:17822891.

JAFARINEJAD, H., MOGHOOFEI, M., MOSTAFAEI, S., SALIMIAN, J., AZIMZADEH JAMALKANDI, S. and AHMADI, A., 2017. Worldwide prevalence of viral infection in AECOPD patients: A metaanalysis. Microbial Pathogenesis, vol. 113, pp. 190-196. http:// dx.doi.org/10.1016/j.micpath.2017.10.021. PMid:29038056. 
JÓNSDÓTTIR, B., JAWOROWSKI, Å., SAN MIGUEL, C. and MELANDER, O., 2017. IL-8 predicts early mortality in patients with acute hypercapnic respiratory failure treated with noninvasive positive pressure ventilation. BMC Pulmonary Medicine, vol. 17, no. 1, pp. 35. http://dx.doi.org/10.1186/s12890-017-0377-7. PMid:28178959.

KO, F.W., CHAN, P.K., CHAN, R.W.Y., CHAN, K.P., IP, A., KWOK, A., NGAI, J.C., NG, S.S., ON, C.T. and HUI, D.S., 2019. Molecular detection of respiratory pathogens and typing of human rhinovirus of adults hospitalized for exacerbation of asthma and chronic obstructive pulmonary disease. Respiratory Research, vol. 20, no. 1, pp. 210. http://dx.doi.org/10.1186/s12931-019-1181-0. PMid:31519188.

KOUL, P.A., MIR, H., AKRAM, S., POTDAR, V. and CHADHA, M.S., 2017. Respiratory viruses in acute exacerbations of chronic obstructive pulmonary disease. Lung India : Official Organ of Indian Chest Society, vol. 34, no. 1, pp. 29-33. http://dx.doi. org/10.4103/0970-2113.197099. PMid:28144057.

KOUTSOKERA, A., KOSTIKAS, K., NICOD, L.P. and FITTING, J.W., 2013. Pulmonary biomarkers in COPD exacerbations: a systematic review. Respiratory Research, vol. 14, no. 1, pp. 111. http://dx.doi. org/10.1186/1465-9921-14-111. PMid:24143945.

KURAI, D., SARAYA, T., ISHII, H. and TAKIZAWA, H., 2013. Virusinduced exacerbations in asthma and COPD. Frontiers in Microbiology, vol. 4, pp. 293. http://dx.doi.org/10.3389/ fmicb.2013.00293. PMid:24098299.

KWAK, H.J., PARK, D.W., KIM, J.E., PARK, M.K., KOO, G.W., PARK, T.S., MOON, J.Y., KIM, T.H., SOHN, J.W., YOON, H.J., SHIN, D.H. and KIM, S.H., 2016. Prevalence and Risk Factors of Respiratory Viral Infections in Exacerbations of Chronic Obstructive Pulmonary Disease. The Tohoku Journal of Experimental Medicine, vol. 240 , no. 2, pp. 131-139. http://dx.doi.org/10.1620/tjem.240.131. PMid:27725531.

LOPEZ, A.D., SHIBUYA, K., RAO, C., MATHERS, C.D., HANSELL, A.L., HELD, L.S., SCHMID, V. and BUIST, S., 2006. Chronic obstructive pulmonary disease: current burden and future projections. The European Respiratory Journal, vol. 27, no. 2, pp. 397-412. http:// dx.doi.org/10.1183/09031936.06.00025805. PMid:16452599.

MARTINELLO, R.A., ESPER, F., WEIBEL, C., FERGUSON, D., LANDRY, M.L. and KAHN, J.S., 2006. Human metapneumovirus and exacerbations of chronic obstructive pulmonary disease. The Journal of Infection, vol. 53, no. 4, pp. 248-254. http://dx.doi. org/10.1016/j.jinf.2005.11.010. PMid:16412516.

MATSUMOTO, K. and INOUE, H., 2014. Viral infections in asthma and COPD. Respiratory Investigation, vol. 52, no. 2, pp. 92-100. http://dx.doi.org/10.1016/j.resinv.2013.08.005. PMid:24636264.

PANT, S., WALTERS, E. H., GRIFFITHS, A., WOOD-BAKER, R., JOHNS D. P. and REID, D. W., 2009. Airway inflammation and antiprotease defences rapidly improve during treatment of an acute exacerbation of COPD. Respirology, vol. 14, no. 4, pp. 495-503. http://dx.doi.org/10.1111/j.1440-1843.2009.01517.x.

PEROTIN, J.M., DURY, S., RENOIS, F., DESLEE, G., WOLAK, A., DUVAL, V., DE CHAMPS, C., LEBARGY, F. and ANDREOLETTI, L., 2013. Detection of multiple viral and bacterial infections in acute exacerbation of chronic obstructive pulmonary disease: A pilot prospective study. Journal of Medical Virology, vol. 85, no. 5, pp. 866-873. http://dx.doi.org/10.1002/jmv.23495. PMid:23447038.

PIPER, S.C., FERGUSON, J., KAY, L., PARKER, L.C., SABROE, I., SLEEMAN, M.A., BRIEND, E. and FINCH, D.K., 2013. The role of interleukin-1 and interleukin-18 in pro-inflammatory and anti-viral responses to rhinovirus in primary bronchial epithelial cells. PLoS One, vol. 8, no. 5, pp. e63365. http://dx.doi.org/10.1371/journal. pone.0063365. PMid:23723976.

STRIETER, R.M., BELPERIO, J.A. and KEANE, M.P., 2003. Host innate defenses in the lung: the role of cytokines. Current Opinion in Infectious Diseases, vol. 16, no. 3, pp. 193-198. http://dx.doi. org/10.1097/00001432-200306000-00002. PMid:12821807.

TRIANTAFILOU, K., KAR, S., VAN KUPPEVELD, F.J. and TRIANTAFILOU, M., 2013. Rhinovirus-induced calcium flux triggers NLRP3 and NLRC5 activation in bronchial cells. American Journal of Respiratory Cell and Molecular Biology, vol. 49, no. 6, pp. 923-934. http://dx.doi.org/10.1165/rcmb.2013-00320C. PMid:23815151.

VESTBO, J., HURD, S.S., AGUSTI, A.G., JONES, P.W., VOGELMEIER, C., ANZUETO, A., BARNES, P.J., FABBRI, L.M., MARTINEZ, F.J., NISHIMURA, M., STOCKLEY, R.A., SIN, D.D. and RODRIGUEZROISIN, R., 2013. Global strategy for the diagnosis, management, and prevention of chronic obstructive pulmonary disease: GOLD executive summary. American Journal of Respiratory and Critical Care Medicine, vol. 187, no. 4, pp. 347-365. http://dx.doi. org/10.1164/rccm.201204-0596PP. PMid:22878278.

WEDZICHA, J.A. and SEEMUNGAL, T.A., 2007. COPD exacerbations: defining their cause and prevention. Lancet, vol. 370, no. 9589, pp. 786-796. http://dx.doi.org/10.1016/S0140-6736(07)613828. PMid:17765528.

WORLD HEALTH ORGANIZATION - WHO. 2019. [viewed 19 Sept 2019]. Chronic respiratory diseases: Burden of COPD [online]. Retrieved from https://www.who.int/respiratory/copd/ burden/en/.

WILKINSON, T.M., HURST, J.R., PERERA, W.R., WILKS, M., DONALDSON, G.C. and WEDZICHA, J.A., 2006. Effect of interactions between lower airway bacterial and rhinoviral infection in exacerbations of COPD. Chest, vol. 129, no. 2, pp. 317324. http://dx.doi.org/10.1378/chest.129.2.317. PMid:16478847.

YIN, T., ZHU, Z., MEI, Z., FENG, J., ZHANG, W., HE, Y., SHI, J., QIAN, L., LIU, Y., HUANG, Q., HU, Y. and JIE, Z., 2018. Analysis of viral infection and biomarkers in patients with acute exacerbation of chronic obstructive pulmonary disease. The Clinical Respiratory Journal, vol. 12, no. 3, pp. 1228-1239. http://dx.doi.org/10.1111/ crj.12656. PMid:28586150.

ZHANG, J. and BAI, C., 2018. The Significance of Serum Interleukin-8 in Acute Exacerbations of Chronic Obstructive Pulmonary Disease. Tanaffos, vol. 17, no. 1, pp. 13-21. PMid:30116274.

ZHENG, J., SHI, Y., XIONG, L., ZHANG, W., LI, Y., GIBSON, P.G., SIMPSON, J.L., ZHANG, C., LU, J., SAI, J., WANG, G. and WANG, F., 2017. The Expression of IL-6, TNF-alpha, and MCP-1 in Respiratory Viral Infection in Acute Exacerbations of Chronic Obstructive Pulmonary Disease. Journal of Immunology Research, vol. 8539294, pp. 8539294. http://dx.doi.org/10.1155/2017/8539294. PMid:28352642. 